\title{
O APOCALIPSE DA ESCRITA EM A FÚRIA DO CORPO, DE JOÃO GILBERTO NOLL
}

\section{L'APOCALYPSE DE L'ÉCRITURE DANS A FÚRIA DO CORPO, DE JOÃO}

GILBERTO NOLL

Francisco Renato de Souza*

RESUMO: Este artigo analisa três elementos narrativos essenciais na composição da escrita da obra $A$ fúria do corpo, de João Gilberto Noll, a saber: a não-nomeação do narrador, a errância como força propulsora do discurso ficcional e a cidade enquanto espaço imprescindível e intransponível que mobiliza todo e qualquer movimento presente na narrativa nolliana em questão. Uma vez que releituras de textos bíblicos, como o Livro do Gênesis e o Livro do Apocalipse, tecem a trama textual da narrativa de Noll e se destacam como a base da intensa errância de seus personagens principais, este artigo propõe também um diálogo enre os tr̂s elementos narrativos destacados e a mitologia cristă. Como fundamentação té́rica, destacam-se Jean-Yves Leloup, Como fundamentaçăo teórica, destacam-se Jean-Yves Leloup, estudioso de textos bíblicos, e Maurice Blanchot, pensador da linguagem literária.

PALAVRAS-CHAVE: Noll; Errância; Apocalipse; Escrita; Cidade
* paconato_@hotmail.com

Doutor em Teoria Literária e pós-doutorando pelo Departamento de Ciência da Literatura da Universidade Federal do Rio de Janeiro.

RÉSUMÉ: Cette article examine trois éléments narratifs essentiels présents dans la composition de l'écriture de l'œuvre $A$ fúria do corpo, de João Gilberto Noll, à savoir: la non-dénomination du narrateur, l'errance en tant que moteur du discours fictionnel et la ville en tant qu'espace indispensable et insurmontable qui s'accapare de tout mouvement présent dans le récit nollien concerné. Etant donné que les relectures de textes bibliques, comme le Livre de la Genèse et le Livre de l'Apocalypse, tissent l'intrigue textuelle du récit de Noll et sont mises en exergue comme étant la base de principaux, cet article propose aussi un dialogue entre les tros ććmoux, cet êlements narratifs mis en evidence et la mythologie chrétienne. Comme fondement théorique, on remarque Jean-Yves Leloup théologien, et Maurice Blanchot, critique littéraire.

MOTS-CLÉS: Noll; Errance; Apocalypse; Écriture; Ville. 
1. NOLL. $A$ fúria do corpo, p. 9

2. NOLL. A fúria do corpo, p. 10.
Feliz aquele que lê as palavras desta profecia e felizes aqueles que ouvem e guardam o que nela está escrito, porque o tempo está

próximo.

Livro do Apocalipse

1. A PROFECIA DE JOÃO: A NÃO-NOMEAÇÃO

A narrativa de $A$ fúria do corpo, primeiro romance do escritor João Gilberto Noll, se inicia por uma negação: "O meu nome não." A partir dessa recusa, o narrador da obra estabelece outras imposições para a continuidade da sua narração: entre elas, deixar de fora o seu passado e estabelecer o início de sua enunciação como o ponto de partida da ação, demarcando também o espaço em que esta se desenvolverá, o bairro de Copacabana, na cidade do Rio de Janeiro: "[...] aqui a história se inicia e nada mais importa, um homem e uma mulher se reconhecem em plena Atlântica, não termos pouso nem casa não importa, aqui começa o esplendor de uma miséria, seguirmos é só isso [...]."2 Assim, o início da narração de A fúria do corpo é feita em uma espécie de prefácio, no qual o narrador estabelece algumas prerrogativas para o desenvolvimento do enredo que enunciará. Ocultar o seu verdadeiro nome é a primeira delas. $\mathrm{O}$ nome verdadeiro do outro personagem, sua companheira, ta mbém não será revelado, mas este não permanecerá anônimo, ganhará um nome decidido pela voz narrativa que, entre a sua recusa inicial em se autonomear e o batismo da companheira que o acompanhará na quase totalidade da ação do enredo, estabelecerá as demais condições que conduzirão a narrativa.

Ao interferir na composição do texto, a ação subjetiva da voz desse narrador vai, portanto, além do duplo ato de vivenciar aquilo que se narra; ela é também a elaboradora dessa escrita. Uma voz que não se limitará apenas à narração da ação, mas que a direcionará. A negação do narrador pode, então, ser lida como uma recusa à unificação de suas possibilidades de significação, pois se deixar nomear seria se deixar rotular pelas regras vigentes na linguagem do mundo corrente: "Quando criança me ensinaram assim: nome, idade, endereço, escola, cor preferida. Não, não vou entregar ao primeiro que aparece; nome, idade, essas coisas soterram um tesouro: sou todos, e quando menos se espera, ninguém." ${ }^{3}$ Sua recusa seria uma resistência em se deixar aprisionar por um significante que o remeteria diretamente a um único significado, almejando assim a pluralidade que só a a mbiguidade da palavra literária permite. Dessa forma, a partir da recusa do narrador de Noll, entrevemos duas formas de linguagem que se opõem: a linguagem do mundo corrente e a linguagem própria do fazer literário. 
O contraponto entre essas duas formas de linguagem é a nalisado pelo escritor francês Maurice Blanchot, no texto "A litera tura e o direito à morte", do livro A parte do fogo, no qual ele explicita os efeitos opostos que as duas linguagens exercem: tranquilizador na fala do mundo corrente, inquietante na fala da escrita literária. Segundo Blanchot, a linguagem no mundo corrente é utilitária, uma vez que, ao dar-nos o domínio das coisas a través de sua nomeação, possibilita-nos a facilidade e a segurança na vida. Assim, nomear o mundo é uma forma de apossar-se dele. Todavia, o teórico enfatiza a perda da relação do significante com o objeto, provocada por seu uso cotidia no constante, que distancia a palavra do encanto original da sua utilização. O significado nos chega através do significante, mas suprimindo o objeto, privando-o do seu ser, que permanece apenas de forma residual.

Desse modo, Blanchot aponta o ato de nomear como o ato de matar o ser, de aniquilá-lo, ao reter dele somente a sua ausência, o que ele não é, e exemplifica, ao dizer que nomear um gato é fazer dele um não-gato, que cessa de existir, deixa de ser o gato vivo, já que o gato vivo e seu nome não são idênticos. Porém, enfatiza que, se a palavra, na linguagem comum, exclui a existência do que designa, ainda se remete a ela pela inexistência que se tornou a ausência dessa coisa:
Essa é a primeira diferença entre linguagem comum e linguagem literária. A primeira admite que a não-existência do gato, uma vez passada para a palavra, leva a que o próprio gato ressuscite plena e certamente como sua ideia (seu ser) e como seu sentido: a palavra lhe restitui, no plano de ser (da ideia), toda a certeza que ela tinha no plano da existência. ${ }^{4}$

A linguagem literária, no entanto, é diferente, é feita de inquietudes e de contradições, tem uma posição instável e pouco sólida. Ela só se interessa pelo sentido da coisa, por sua ausência, que desejaria alcançar nela mesma e por ela mesma. Enfatiza ainda Blanchot que, para a linguagem literária, a palavra gato não é apenas a não-existência do gato, mas a não-existência que se tornou palavra: uma realidade determinada e objetiva. Entretanto, só transpor a irrealidade da coisa para a realidade da linguagem não é o suficiente, e assim se questiona: "De que maneira a ausência infinita da compreensão poderia aceitar confundir-se com a presença limitada e tacanha de uma palavra só?" ${ }^{5} \mathrm{O}$ teórico, então, conclui que a palavra não basta para toda a verdade que ela contém. E se a linguagem do mundo corrente se engana, na linguagem literá ria o nada do qual ela é feita trava uma luta em cada palavra procurando uma saída, em uma infinita inquietude para romper com o lacre que a aprisiona e só então ter acesso a outros nomes, "menos fixos, ainda indecisos, mais capazes de se reconciliar

EM TESE BELO HORIZONTE $\quad$ v. $24 \quad$ N. 2 MAlO-AG0. 2018 SOUZA. 0 apocalipse da escrita em A fúria do corpo, de João Gilberto Noll P. 23-41


7. NOLL. A fúria do corpo, p. 9.

8. NOLL. A fúria do corpo, p. 9

9. NOLL. A fúria do corpo, p. 9 com a liberdade selvagem da essência negativa, dos conjuntos instáveis, não mais dos termos, mas de seu movimento deslizamento sem fim de 'expressões' que não chegam a lugar nenhum." ${ }^{\prime 6}$ Nasce assim, segundo Bla nchot, a imagem do texto literário, que não designa diretamente a coisa, mas que oscila entre cada palavra, procurando retomá-las todas e negando todas ao mesmo tempo.

Essa seria, portanto, a instabilidade que o narrador de Noll busca em A fúria do corpo, ao não se deixar aprisionar por uma nomeação que lhe reduziria ao imutável, que empobreceria suas possibilidades de significação, optando por ser as muitas apresentações que lhe são possíveis somente no terreno fértil da escrita literária: "Mas se quiser um nome pode me chamar de Arbusto, Carne Tatuada, Vento."7 Não sendo apenas aquele que o seu nome identificaria, multiplica-se e locomove-se na narrativa sem se deixar aprisionar: "O meu nome de hoje poderá não me reconhecer amanhã. Não soldo portanto à minha cara um nome preciso." ${ }^{8}$ Todavia, a sua negação inicial de se autonomear é seguida de uma revelação: "Me chame como quiser, fui consagrado a João Evangelista, não que o meu nome seja João, absolutamente, não sei de quando eu nasci, nada, mas se quiser o meu nome busque na lembrança o que de mais instável the ocorrer." $\mathrm{O}$ narrador, assim, diz-se consagrado a João Evangelista, um dos doze apóstolos de Jesus Cristo, a quem é dada a autoria do evangelho de João, das três epístolas de João e do Livro do Apocalipse, textos do Novo Testamento da Bíblia.

Porém, em todas essas atribuições paira um questionamento sobre a fidedignidade da autoria de João sobre esses escritos. Sobre o evangelho de João, diz-se: "O autor é o apóstolo João, 'discípulo a quem Jesus a mava'. Era de grande destaque na igreja primitiva, mas não é mencionado por nome neste evangelho - fa to que seria natural se fosse o autor, mas de outra forma seria de difícil explicação."10 Sobre as três cartas de João, é-lhe atribuída a autoria, mas permanece a mbiguidade sobre o anonimato do autor como em 1João: "Ao contrário da maioria das cartas do novo testamento, 1João não declara o autor." ${ }^{11}$ A a utenticidade de João Evangelista como o autor das duas outras cartas é confirmada por sua semelhança escritural, tanto em relação à primeira carta, como em relação ao evangelho de João e ao Livro do Apocalipse, texto no qual o autor se apresenta quatro vezes como João, e que, apesar de questionamentos posteriores sobre a sua autoria, apoia-se veementemente a concepção tradicional que sustenta o evangelista como a utor do Livro das revelações.

O estudioso de textos bíblicos Jean-Yves Leloup, em $O$ evangelho de João, faz uma leitura desse evangelho, a partir
10. Bíblia de estudo NVI, Introdução: João, p. 1784.

1. Bíblia de estudo NVI, Introdução: 1João, p. 2147. 
12. LELOUP. O evangelho de João, $\mathrm{p}$.

13. LELOUP. O evangelho de João, $\mathrm{p}$.

14. LELOUP. O evangelho de João, p. de numerosos estudos, reconhecendo o seu texto "como braseiro, entrelaça mento de significações, tradição viva, desvelamento de uma presença", ${ }^{12}$ e, sobre os questionamentos que tantas e diversificadas leituras suscitam sobre a autoria do texto, cita a solução radical proposta para tornar supérfluas todas as tentativas de identificação histórica do autor, causadas por suas múltiplas representações: "João, o discípulo bem-a mado, não seria uma personalidade histórica, mas antes uma figura simbólica, o símbolo do discípulo ideal." ${ }^{13}$

Sendo assim, o santo ao qual o narrador de Noll se diz consagrado traz já na sua concepção uma gama de possibilidades identificatórias:

Sacerdote sábio, pescador das margens do Lago, filho de Maria, filho do trovão, idoso amante, profeta de apocalipse, discípulo bem-amado, águia-apóstolo, teólogo-evangelista... são inumeráveis as fisionomias de João, e se - na iconografia - temos prazer em representá-lo sob a imagem da águia é porque não se deixa apreender facilmente... ${ }^{14}$

No tocante à linguagem, o evangelho de João, e ainda os seus demais textos, como o Livro das revelações, apresenta $\mathrm{m}$ algo ainda mais primordial, apresenta $\mathrm{m}$ a linguagem em sua pluralidade, linguagem não apenas como um simples instrumento de eva ngelização, mas linguagem enqua nto linguagem em toda a sua abrangência, em toda a sua pureza, por isso, talvez, a não-nomeação ou a não-rotulação do seu texto com o seu nome, pois, por ser uma linguagem vinda do divino, em estado absolutamente puro, não deve ser atrelada a nada e nem a ninguém. Assim, João torna-se apenas o emissor das palavras divinas e não o seu dono ou a utor. Heidegger, em $A$ caminho da linguagem, nos fala sobre a linguagem desassociada de marcas de pertença do texto de João:

De acordo com as palavras que abrem o prólogo do Evangelho de São João, no princípio era a palavra e a palavra estava em Deus. Essa posição procurou não apenas libertar a questão da origem das cadeias de uma explicação lógico-racional como também recusar os limites impostos por uma descrição puramente lógica da linguagem. Opondo-se à determinação do significado das palavras exclusivamente como conceitos, essa posição coloca em primeiro plano o caráter figurativo e simbólico da linguagem. ${ }^{15}$

Desse modo, se a fala de João Evangelista é a enunciação do divino, a fala do narrador nolliano, que fora a ele consagrado, traz, então, as características da fala inumana. Nas múltiplas identificações de João Evangelista, o narrador de A fúria do corpo destaca a fala do profeta para justificar a
15. HEIDEGGER. A caminho da linguagem, p. 10-1.
EM TESE
BELO HORIZONTE
v. 24
N. 2
MAIO-AGO. 2018
SOUZA. 0 apocalipse da escrita em A fúria do corpo, de João Gilberto Noll
p. $23-41$ 
sua resistência em se autonomear: "Não soldo portanto à minha cara um nome preciso. João Evangelista diz que as naves do Fim transportarão não identidades mas o único corpo impregnado do Um." ${ }^{16} \mathrm{O}$ Fim que surge nas visões do apóstolo João se refere ao fim da impunidade humana e previsto no Apocalipse, último livro do Novo Testa mento bíblico, no qual o profeta evangelista discorre em uma linguagem carregada de simbologia sobre a batalha final entre Deus e Satanás, quando todos os homens, vivos e mortos, serão julgados e o Paraíso Perdido será reconstituído para aqueles que obtiverem a absolvição. O Apocalipse é assim um livro de revelações do destino, do porvir. Sobre a linguagem utilizada nesse livro, Leloup, em Apocalipse: clamores da revelação, diz:

[...] é um gênero literário encontrado na Bíblia, já no Antigo Testamento, no Livro de Daniel, por exemplo. Nós a encontramos em algumas visões dos profetas. Nos livros de Ezequiel e de Isaías existem também apocalipses, isto é, desvelamento da realidade, desvelamento do sentido, desvelamento este que é comunicado a través de imagens e de símbolos. ${ }^{17}$

Dessa forma, o Livro das revelações é um gênero literário, o dos escritos de profecias. Ordinariamente, a profecia é uma predição do futuro. Para Blanchot, no entanto, a profecia não é apenas uma fala futura, uma vez que, quando a palavra torna-se profética não é o futuro que é dado e sim o presente que é retirado. Em "A palavra profética", de O livro por vir, Blanchot afirma que a fala profética anuncia um futuro impossível, talvez porque faz o futuro que anuncia ser impossível justamente porque o anuncia, transtornando a segurança da existência nesse futuro onde não podería mos viver. Assim, o a núncio do porvir se desenvolve no momento presente, mas sempre intentando o momento que ainda está por chegar e que, no entanto, já se adianta na forma do anúncio, sendo assim uma fala em constante devir: "A fala profética é uma fala errante que volta à exigência ordinária de um movimento, opondo-se a toda estabilidade, toda fixação a um enraizamento que seria repouso." 18

Ao consagrar-se ao apóstolo das revelações, o narrador de Noll insere na sua narrativa a linguagem da profecia, a promessa da revelação, que, na suposição de lhe trazer o futuro, lhe retira o momento presente, e com ele toda estabilidade possível, arrastando a si e a sua companheira para o movimento incessante e interminável da errância apocalíptica, uma vez que, como afirma ainda Bla nchot "Quando a palavra se torna profética, não é o futuro que é dado, é o presente que é retirado, e toda possibilidade de uma presença firme, estável e durável." ${ }^{19}$ Pois, se no início
18. BLANCHOT. O livro por vir, p. 114 
da na rrativa de A fúria do corpo, o narrador estabeleceu um corte definitivo com o passado, por diversas vezes volta-se para ele e, apesar de focar sua narrativa no momento presente à enunciação, traz o futuro a esse presente na fala que se desenvolve no agora, porém, voltada para o que ainda está por vir. Se a voz do profeta carrega em sua fala a profecia, como o a núncio do fim, na obra de Noll o narrador consagrado ao profeta evangelista tem em Afrodite, como a enunciação dessa fala, a voz da promessa do verbo divino, a anunciação do Apocalipse:

[...] indefeso peço proteção a Afrodite, ela me fala coisas enternecidas, diz que um dia tudo há de se esclarecer, os tiranos de um lado os injustiçados do outro, e haverá uma linha de fogo separando as duas hordas, os déspotas malditos ainda terão tempo de apreciar o paraíso sem fim dos outrora injustiçados. ${ }^{20}$

A fala de Afrodite intenta o momento apocalíptico, no qual, após o julga mento final divino, os que obtiverem absolvição terão o retorno ao estado perfeito usufruído pelo homem no Éden, no começo da história humana, como mostra a visão do apóstolo João em uma passagem do Livro das revelações: "Já não haverá maldição nenhuma. O trono de Deus e do Cordeiro estará na cidade, e os seus servos o servirão. Eles verão a sua face, e o seu nome esta rá em suas testas. Não haverá mais noite. Eles não precisarão de luz de candeia, nem da luz do sol, pois o Senhor Deus os iluminará; e eles reina rão para todo o sempre." ${ }^{21}$ A esperança no restabelecimento do paraíso terrestre, estado original do homem, é o desejo humano de estabilização. O Paraíso, com sua denotação de paz, se configura como a oposição ao estado apocalíptico, de natureza destruidora, mas que, no entanto, é o estado anterior ao momento final que possibilitará a obtenção do descanso, da estabilidade, no chamado paraíso terrestre.

\section{O PARAÍSO PERDIDO: A ERRÂNCIA}

A possibilidade do Paraíso para os personagens de Noll se dá na esperança da saída da cidade em direção ao campo, para uma moradia na casa da tia de Afrodite, em meio à natureza. Assim, o narrador e sua companheira perambulam incessantemente pelas ruas da cidade, impelidos pela errância, na intenção de um pouso final. Entretanto, a promessa de uma vida ordinária mostra-se vã, pois a saída da cidade não lhes é possível: "Afrodite inclina a cabeça e me olha toda compadecida, me confessa quase em sussurros que a tia no Sul nunca existiu, nem muito menos um mato pra onde ir, nada, estamos ilhados na Cidade, nem horta nem pomares, nenhum cais onde aportar o nosso idílio [....."22 A errância do narrador foi, assim, impelida pelo ardil feminino, pela falsa promessa de um pouso final. Assim
21. Bíblia de estudo NVI. Apocalipse, v. 22,5, p. 2195
EM TESE
BELO HORIZONTE
v. 24
N. 2
MAIO-AGO. 2018
SOUZA. 0 apocalipse da escrita em A fúria do corpo, de João Gilberto Noll
p. $23-41$ 
como em A fúria do corpo, a linguagem está na origem do desvio da humanidade rumo à sua destruição prevista no Apocalipse.

O primogênito dos homens, Adão, ao aceitar comer do fruto da árvore do conhecimento, oferecido por sua companheira Eva, condenou toda a sua descendência aos martírios que só cessariam no julga mento final divino. Eva fora seduzida pelo ardil de Satanás, que a aliciou transmutado em forma de serpente. A Serpente tem muitas faces e na obra de Noll, na adolescência do menino interno, na admoestação dos padres do internato, ela viria na mais perigosa dessas faces, aquela que alicia pela palavra na sedução do sexo: "[...] o Sa tanás que o padre explanava revelando a astúcia sem par das palavras desse ente ardiloso que se mete nas situações mais inesperadas sob a face de porcelanas e carmins inebriantes de mulheres da vida e pederastas milionários [...]." ${ }^{23}$ A linguagem imiscuída no sexo seria, pois, o perigo máximo a ser evitado. $O$ perigo que, no entanto, estaria no alicerce da evasão do ouvinte dos sermões, que então o canalizaria em uma narrativa propulsionada pelo sexo, elemento elaborador de sua escrita.

Pois o sexo, na narrativa de A fúria do corpo, é o meio de ligação mais visceral entre o narrador e Afrodite, e entre eles e os demais personagens. E se entendermos a relação do narrador com o personagem feminino como a relação da voz enunciadora e da sua enunciação, Afrodite, sendo o próprio processo narrativo, enunciação, escrita e linguagem como um todo, seria a imagem fecunda e fértil da voz narrativa. A imagem representativa do desejo que, através do sexo, na obra, é a forma incisiva de estabelecer o desenvolvimento da escrita: "Não me pergunte pois idade, estado civil, local de nascimento, filiação, pegadas do passado, nada passado não, nome também: não. Sexo, o meu sexo sim: o meu sexo está livre de qualquer ofensa, e é com ele-só-ele que abrirei caminho entre eu e tu, aqui." ${ }^{24}$ Assim, no "aqui", o espaço literá rio, entre a voz de elaboração, o narrador, e a sua escrita, o personagem Afrodite, o sexo se apresentará como o elo de concretização da linguagem.

O corpo passa, assim como a palavra, a ser o contingente da linguagem literá ria, o ca minho pelo qual se faz a errância dos dois personagens: "E cada encontro nos lembrava que o único roteiro é o corpo. O corpo." ${ }^{25}$ A fúria do corpo é a fúria do sexo que é a fúria da escrita. Assim sendo, na obra de Noll, o sexo reúne a santíssima trindade no nome de Afrodite, que passa a ser o único corpo impregnado do Um que fora previsto em uma das visões do Juízo Final de João Evangelista, citada anteriormente pelo narrador nollia no: "Me aproximo mais, recomeço: Afro. Frodi. Dite. São os teus três nomes, continuo sussurrando. Afro para 
26. NOLL. A fúria do corpo, p. 183.

27. NOLL. A fúria do corpo, p.14. o sexo. Frodi para as horas de peraltice. Dite para teu encanto humano. Os três conheço reunidos em Afrodite. Uma coisa só. Só uma reúne todos." ${ }^{26}$ Pois se o narrador, assim como fizera com a sua própria nomeação, inicialmente se recusa a revelar a verdadeira identidade da companheira, não deixa este personagem com uma nomeação indefinida, batizando-a com o nome de Afrodite.

E, assim como detém o poder de interferir na nomeação dos personagens, a voz narrativa mostra deter o poder de estabelecer uma múltipla e peculiar significação para a nomeação escolhida, ao dar-lhe uma gama de significados definidos arbitrariamente: "[...] darei a esta mulher um nome que não se encontra em nenhum cartório, um nome que não dará meu rastro ao inimigo, um nome que une a força dos astros, um nome cujo desempenho estará sempre lá onde o guarda mos [...]."27 Estabelece uma nomeação, porém não permite o aprisionamento deste nome a um só significado. Entretanto, obstante o múltiplo significado estabelecido pelo narrador para o nome da companheira, este é derivado de uma escolha. Não sendo um significante originado unicamente da fala narrativa da obra em questão, traz uma referência da linguagem do mundo que remete à simbologia da mitologia grega: Afrodite é a deusa do amor e representa a fertilidade e a fecundidade..$^{28}$
Seu nascimento é cantado pelo poeta grego Hesíodo no poema Teogonia, a origem dos deuses, obra que mostra a organização do mundo dos deuses gregos e apresenta sua genealogia, sua linhagem e sua distribuição de posicionamentos e honras. O poema é fruto de uma revelação divina feita ao pastor Hesíodo, quando este pastoreava ovelhas no monte Helícon, pelas Musas, filhas de Zeus, figura máxima no panteão dos deuses olímpicos e Mnemosýne, Memória, sendo assim, ta mbém, uma noção mítica de linguagem como manifestação divina.

Nascida da espuma branca que fermentou no mar quando o pênis ceifado de Urano fora ali arremessado por seu filho e ceifador Cronos, desde sua emersão das águas, a Afrodite mitológica teve como acompanhantes Eros e Desejo, deuses representativos do Amor e da vontade de união dos sexos, como canta Hesíodo:

A ela. Afrodite/ Deusa nascida de espuma e bem-coroada Citeréia/ apelidam homens e Deuses, porque da espuma/ criou-se e Citeréia porque tocou Citera/ Cípria porque nasceu na undosa Chipre,/ e Amor-do-pênis porque saiu do Pênis à luz./ Eros acompanhou-a, Desejo seguiu-a belo/ tão logo nasceu e foi para a grei dos Deuses. ${ }^{29}$
29. HESÍODO. Teogonia, a origem dos deuses, p. 115-7. 
30. SISSA E DETIENNE. Deuses gregos, p. 267.

31. Bíblia de estudo NVI. Gênesis, v. 2,19, p. 9.
A Afrodite mitológica é, assim, símbolo da fecundidade e da fertilidade, figura representativa da união dos opostos a través do sexo, como afirmam Giulia Sissa e Marce Detienne, no texto "Um falo para Dioniso", do livro Deuses gregos: "Afrodite reina sobre o prazer sexual, sobre o ato de 'fazer a mor', sobre os corpos que se misturam, sobre os viventes levados a entrelaçar seus membros, suas formas, quer pertença $\mathrm{m}$ ao mundo dos animais ou à espécie humana." ${ }^{30}$ A escolha do nome da deusa do amor e do sexo, representante da fecundidade e da fertilidade, pelo narrador na obra de Noll para a sua companheira, não sendo entendida por nós como aleatória, seria uma a nalogia à representação do mito grego, já que é pelo sexo que a comunicação entre o narrador e o personagem Afrodite se estabelecerá de forma mais pungente no romance de Noll.

O narrador de $A$ fúria do corpo assemelha-se ainda ao primeiro homem da mitologia cristã, Adão, que nomeou todos os seres postos na terra por Deus: "Depois que formou da terra todos os animais do campo e todas as aves do céu, o Senhor Deus os trouxe ao homem para ver como este lhes chamaria; e o nome que o homem desse a cada ser vivo, esse seria o seu nome." ${ }^{31}$ Após nomear todos os seres viventes, faltava ainda ao primeiro homem uma companheira. Esta fora então criada por Deus, a partir da costela de Adão - que a nomeou com o nome que justificaria a sua função:
"Adão deu à sua mulher o nome de Eva, pois ela seria mãe de toda a humanidade." ${ }^{32}$ - começando assim, com o primeiro casal, a origem da humanidade. Por delegação divina, Adão torna-se o nomeador das coisas do mundo e de todos os seus viventes, iniciando então o domínio dos homens sobre as coisas pela palavra, como ilustra a seguinte citação de Hegel, apontada por Blanchot: "O primeiro ato, com o qual Adão se tornou senhor dos animais, foi lhes impor um nome, isto é, a niquilá-los na existência (como existentes)."33

As passagens introdutórias do livro do Gênesis, a criação do mundo e dos seres viventes, é o marco inicial dessa origem. A concepção criativa da enunciação do narrador de Noll se assemelha ao mesmo processo do texto da criação bíblica, por uma voz com a utoridade para nomear e estabelecer as condições nas quais a ação se desenvolverá, e que tem seu marco inicial em um espaço definido e limitado em um tempo que não tem passado, no movimento de dois personagens inaugurais:

[...] os nossos nomes não serão pronunciados até que chegue o dia de serem proclamados, já toquei nos teus lábios vaginais, já penetrei entre eles, o meu sexo sim, o nosso sexo, e agora é tudo como se fosse nossa origem e esses lábios túrgidos, meu pau la teja como um animal farejando os umbrais do paraíso, aqui a história se inicia e nada mais importa [...]." ${ }^{34}$
32. Bíblia de estudo NVI. Gênesis,v. 3,20, p. 11 .

33. BLANCHOT. A parte do fogo, $\mathrm{p}$. 311.
EM TESE
BELO HORIZONTE
v. 24
N. 2
MAIO-AGO. 2018
SOUZA. 0 apocalipse da escrita em A fúria do corpo, de João Gilberto Noll
p. $23-41$ 
Todavia, enunciada na escrita literária, essa concepção não se volta para as coisas práticas do mundo, daí a omissão da verdadeira nomeação dos personagens, e nem para a doutrina da linguagem cristã, pois foge da concepção do sexo como noção de pecado e de perdição, já que, para o narrador, o sexo se institui como elemento primordial e essencial da sua concepção criativa.

No que se refere ao paraíso bíblico, intensas são as leituras sobre o sexo como elemento inerente ou não ao delito que levou à expulsão do primeiro casal do Jardim do Éden, e à sua consequente errância de martírios, e que teve como motivo maior a desobediência da ordem divina de não provarem os dois do fruto da árvore do conhecimento. Feito o delito, primeiro por parte da mulher, seduzida pela Serpente, em seguida pelo homem, que ta mbém provou do fruto proibido, a primeira mudança se deu na percepção e na reparação de a mbos da sua nudez. Haroldo de Campos, no prefácio explicativo da sua transcrição do episódio, intitulado Éden, cita algumas interpretações para a perda da inocência humana. Para Harold Bloom, além da triste cognição da morte, a mulher teria ga nho ta mbém a "previamente não existente consciência da sexualidade, através do seu signo da desnudez" ${ }^{35}$ Em outra leitura de Bloom, a vergonha decorreria de algo mais amplo do que a conotação sexual referida antes por ele, decorreria do conhecimento da "liberdade e dos limites da liberdade" ${ }^{36}$

Campos cita ainda Octavio Paz que, na conclusão de seu livro sobre a mor e erotismo, A Dupla Chama, "encontra justamente em Adão e Eva 'um casal que abarca todos os casais' e vê no seu pecado e na sua história 'um contínuo corpo a corpo com o tempo sem corpo' a ser reinventado por todo 'casal de amantes.' "' Essas interpretações sobre a inocência perdida com a nudez de Adão e Eva ser restrita à sexualidade ou abranger componentes mais gerais como liberdade ou consciência, decorrentes das muitas possibilidades de leituras da Bíblia, não se verifica na obra de Noll, onde toda e qualquer ação do enredo é permeada pelo ato do sexo. A saga dos dois personagens, quando vista em relação à do primeiro casal bíblico, destoa na percepção e recepção do elemento sexual como negativo, se visto como pecado, para algo não só bem mais aceito como inclusive vital para o desenvolvimento da narrativa.

O sexo que age como propulsor da escrita, a partir de uma relação intrínseca entre a atividade sexual intensa dos personagens e a sua errância, lido como algo em conexão com o divino, portanto distante da leitura bíblica de pecado original, só na sua a usência provoca uma reação semelhante àquela causada no casal inicial bíblico. A vergonha 
pela nudez, tal qual a vivenciada no Jardim Perdido, só é experimentada pelos personagens de Noll na louca corrida desenfreada de a mbos pelas ruas de Copacabana, ao se perceberem impotentes para o sexo e, consequentemente destituídos do mais forte elemento de elaboração da escrita

[...] nós dois fugimos como Adão e Eva expulsos do Paraíso tão não querendo que nenhum olho nos veja que ninguém se aperceba mesmo de Afrodite enrolada em folha de jornal, levada pela minha mão, enrolada em folha de jornal, ninguém percebe o corpo nu de Afrodite sob a folha de jornal, não percebem nem mesmo a folha de jornal, não percebem nem ao menos que hoje Afrodite não é uma mulher como as outras $\left[\ldots . . .^{38}\right.$

O estado primordial perdido pela desobediência do casa edênico traria consequências para toda a sua descendência. O Jardim do Éden, espaço destinado para a vivência de Adão e Eva, com sua perfeição divina, se tornaria um estado inacessível para a humanidade. $\mathrm{O}$ casal de personagens de Noll, no seu tortuoso cotidiano na cidade, se distancia da perfeição primeira do casal bíblico, mas se assemelha à sua condição posterior ao delito que levou à sua expulsão do paraíso - já que, pelo pecado cometido, a mbos foram arremessados ao acaso, ao movimento, à mudança. Humanizados e vivendo sob a condição do pecado, o casal primordial é encontrado na continuidade que lhe dá todo casal de amantes, pois Adão e Eva são, como conclui Octavio Paz, no livro A chama dupla, o começo e o fim de cada casal:

Adão e Eva percorrem esse mundo duro e hostil, povoam-no com seus actos e seus sonhos, humedecem-no com o seu pranto e o suor do seu corpo. Conhecem a glória do fazer e do procriar, o trabalho que gasta o corpo, os a nos que nublam a vista e o espírito, o horror do filho que morre e do filho que mata, comem o pão do castigo e bebem a água da felicidade. $\mathrm{O}$ tempo habita-os e o tempo os desabita. Cada casal de amantes revive a história de Adão e Eva, cada casal sofre a saudade do paraíso [...]..$^{39}$

O narrador nolliano e sua companheira Afrodite erram assim, por um espaço distante daquele destinado aos primogênitos da espécie humana. A perfeição de Adão, criado à imagem e semelhança divina, e de sua companheira Eva que nascera de sua costela, ga nha novos contornos no movimento brutal imposto aos personagens de Noll pelo ritmo da cidade, espaço apocalíptico que não permite a harmonia das formas, já que caótico e inclemente com seus habitantes: "[...] surgiu um macaco extraviado que nos olhou como os primeiros irmãos naquele triste jardim, tão vultosos os rudimentos huma nos que carregáva mos em nossas pobres 
imagens." ${ }^{40}$ A cidade se estabelece como o espaço inicial e demarcado da narrativa nolliana, assemelhando-se ao espaço primeiro criado por Deus para a humanidade, mas que, no entanto, tem sua marca própria, no qual o sexo é o gerador do seu movimento e a proibição divina de evitar o fruto que traria o conhecimento a quem dele provasse é transmutada na proibição do alimento que é negado para quem dele não tenha acesso pela aquisição do dinheiro.

O fruto mordido por Adão e Eva, ilustrado pela maçã ofertada pela Serpente que seduz com a promessa do conhecimento, na obra de Noll é a fruta adquirida pelo furto por dois seres que erram pela cidade na vivência do momento, na tentativa diária de sobrevivência. Afrodite não é induzida e não induz o narrador a cometer o delito da mordida proibida. Ela é o próprio delito, no furto da maçã por ela roubada, que a mbos dividem vorazmente como dois animais nos fundos de um prédio da rua Barata Ribeiro. A escrita não intenta transmitir um conhecimento, e o fruto bíblico que representou a mudança no estado do casal primordial de despercebido para conhecedor da diferença entre o bem e o mal, na dura vida da cidade é só o disputado alimento do famélico casal de personagens de Noll:

[...] seus dentes mordem fundo a pele brilhante da maçã, o branco interior da fruta manchado do sangue dos dentes estragados de Afrodite, aquele sangue deteriorado é a marca da vida de Afrodite na maçã dilacerada pelas mordidas, abocanho ta mbém o vermelho da maçã empurrando Afrodite do meu terreno, quase exigindo que a maçã seja toda minha, dois bichos raivosos diante da presa parca [...]. ${ }^{4}$

\section{BABILONIA E O APOCALIPSE: A CIDADE}

$\mathrm{Na}$ sua miserável errância pelas ruas da Cidade, o narrador se mostra ciente da possibilidade da chegada do dia do descanso final, porém, intenta que a sua realização somente se dará no porvir. Entre o seu momento presente e a estabilização tão ansiada por ele e sua companheira, há o movimento constante e inclemente imposto pela escrita, ao qual, por fim, eles não poderão renunciar. Pois, além do espaço no qual se desenrola a ação do enredo, a cidade da obra, marcada com maiúscula, é a Cidade, personagem que interfere no desenrolar da narrativa, sujeitando todos os outros personagens às condições impostas na vivência do mundo urbano. Espaço literário que é a própria expressão da linguagem, a Cidade toma corpo e se desenvolve à revelia da voz elaboradora do narrador, propiciando o ritmo errante e frenético da narrativa, com seu entrecortado de ruas e movimento intenso.

E o bairro de Copacabana, com o vai e vem constante de transeuntes e trânsito alucinado e ruidoso é o espaço 
no qual a linguagem narrativa de $A$ fúria do corpo encontra condições de se desenvolver com sua fremência peculiar. Copacabana é o marco inicial da narrativa e seu ponto de convergência, comportando, assim, a representação do ritmo acelerado da cidade ficcional que é o ritmo da própria escrita, fornecendo um espaço de movimento intenso e sexo ocasional e frequente que são as marcas de uma linguagem selvagem e vibrante. Com um ritmo particular, que é a marcação do próprio ritmo da linguagem, o bairro se estabelece como um espaço dentro do espaço, uma cidade dentro da cidade, pelo qual a errância dos personagens se desenvolve com mais intensidade, assim como o ritmo das situações vivenciadas por eles.

É assim que, em um breve extravio de Copacabana, na sua passagem com Afrodite pelo bairro da Saúde, o narrador se enleva ao som da doce melodia de Mozart tocada em uma flauta, associada por ele ao estado de deleite do sossego absoluto do paraíso, mas dele se evade consciente da necessidade do constante movimento, que acredita ser necessário para se chegar ao estado de repouso:

[...] apressei os passos como que escondendo o paraíso de Afrodite, ainda tínhamos muita caminhada e não convinha ainda saborear o paraíso, deixei a flauta de Mozart com um aperto no coração mas bastava pra nós dois por enquanto termos dormido na cama de um anjo, outra dose angelical iria nos evadir e não podíamos aceitar evasão quando nos esperava a longa marcha pedindo de nós toda a concentração de forças, um dia reencontro a flauta de Mozart e a mostrarei a Afrodite quem sabe à sombra de dias amenos quem sabe [...]..$^{42}$

O paraíso ao qual o som da flauta o remetia é um estado inviável no movimento inclemente da vida na Cidade, já configurada como um cenário apocalíptico, aquele que traz em si as marcas da anunciação que prevê a destruição como elemento intrínseco da sua revelação:

[...] de repente sirenes intermináveis de bombeiros misturando-se a sirenes de ambulância e da polícia, a Cidade entrava em combustão espontânea, caía em convulsão, assassinava, mas eu ali continuava esmagado sob o peso do dia ainda mais quente que o anterior, o recorde de todos os verões do Rio, eu ali não via a combustão a convulsão o assassina to, só um olhar ou outro de alguma janela sobre minha bunda virada pro céu, a sarna do meu corpo embriagando as moscas à minha volta como numa última ceia, eram puro êxtase as moscas e eu me entregava a elas sem ânimo de espantá-las, as sirenes chocavam-se umas com as outras como as trombetas do Apocalipse e quem sabe a Cidade já estivesse carbonizada com todas as convulsões e os assassinatos consumados [...]. ${ }^{43}$
42. NOLL. A fúria do corpo, p. 143.

43. NOLL. A fúria do corpo, p. 130-1. 
44. REEBER. Religião: termos, conceitos e idéias, p. 138.
O Apocalipse, nas visões do apóstolo João, traz as revelações que cercam o retorno do Messias de Deus, Jesus Cristo, ao mundo dos homens e o julgamento de toda a humanidade, o Juízo Final. Trazendo, desse modo, em si, as noções de paraíso e inferno: a compensação e o castigo para os absolvidos e os condenados, respectivamente, como bem firma Michel Reeber, no livro Religião: termos, conceitos e idéias: "Nas religiões monoteístas, o conceito de inferno está ligado ao princípio da retribuição final: o homem, no Juízo Final, vai para o paraíso ou para o inferno em consequência de seus atos." ${ }^{44}$

A Cidade de Noll, além das marcas apocalípticas, já se configura mesmo como o cenário dos condenados Contrário aos elementos angelicais e paradisíacos apresentados no bairro da Saúde, o narrador e Afrodite percorrem o caminho de volta para Copacabana em meio a sinais de fogo e destruição: “[...] estamos indo novamente em direção a Copacabana, a escuridão carbonizada dos túneis parece galerias do inferno [...]" ${ }^{45}$ A Cidade, assolada por um calor inuma no, arde em bruxuleios de labaredas no asfalto que queima como as paisagens infernais. Um calor que se interna nos personagens, fazendo disso sua força, alimento para o movimento novamente incessante que a escrita lhes impõe, já que o estado de estabilidade que a mbos intentam, associado ao deleite do paraíso, lhes é negado pelo ritmo da escrita que só pode se desenvolver no constante movimento, instável e incessante, apocalíptico e infernal:

[...] descalços sobre o fogo da Cidade nossos corpos adquirem envergadura como se estivessem em chamas, os jornais continuam a clamar o absurdo infernal da temperatura mas nós dois exploramos nossa combustão espontânea que não vem só do Sol mas do interior dos corpos, exploramos essa combustão para fortalecer a ca minhada que se abre mais uma vez à nossa frente [...]. ${ }^{46}$

A Cidade, assim configurada, se contrapõe ao Reino prometido e se estabelece como o estágio último para a sua obtenção. Por isso a necessidade de deixá-la para trás em direção à promessa de Afrodite de um pouso final no sítio da tia no interior, onde haveria a possibilidade de obter o repouso inviável no ritmo citadino:

Saímos pela Atlântica ligados pelo abandono que nos faz andar em direção ao pouso impossível, jogados à sorte do abandono absoluto queremos agora nos sagrar empreiteiros de uma chegada que terá de vir onde for, aqui, na Catalunha, na Terra do Fogo, em Istambul, na Amazônia, em Eldorado, há um pouso isso é certo, um lugar que nos aguarda ainda intocado e ali ficaremos perscrutando os caprichos da terra, os desejos do rio, as manhas do ar $[. . .]^{47}$ 
48. Bíblia de estudo NVI. Apocalipse, v. 21, p. 2194.

49. LELOUP. Apocalipse: clamores da revelação, p. 31.
Na Bíblia, a contraposição do estado catastrófico de uma cidade com o estado idílico de outra, presente em uma das revelações do apóstolo João, se dá após as visões destruidoras do Apocalipse, quando ocorre a destruição da Babilônia para o nascimento de Jerusalém como representação da Terra Prometida, um oásis na terra, sem guerras, dor, sofrimento ou morte: "Então vi novos céus e nova terra, pois o primeiro céu e a primeira terra tinha m passado; e o mar já não existia. Vi a Cidade Santa, a nova Jerusalém, que descia dos céus, da parte de Deus, preparada como uma noiva adornada para o seu marido."48 Babilônia e Jerusalém se contrapõem como representações dos reinos do objeto e do sujeito, do consumo e da comunhão: "Jerusalém é a visão que João terá no fim do Apocalipse. As visões anteriores convenceram-no de que o futuro do mundo não é Babilônia. Há uma outra maneira de viver." ${ }^{49}$

Na narrativa $A$ fúria do corpo, o exílio do espaço urbano em busca do idílio do campo seria, assim, a busca do narrador e de Afrodite por um estado antípoda ao vivenciado por eles na Cidade. O repouso, que o narrador associa ao Reino prometido por Deus, é um benefício que só lhes será permitido em um estágio final, no fim da sua passagem pela Cidade que, na sua configuração infernal, é associada ao caos e ao sofrimento característicos de uma guerra:
[...] saiba que contigo quero casar, encher tua barriga e a casa de filhos, mexer contigo na terra, plantar, lavrar, comer o pão fabricado por nós, escrever memórias, envelhecer na paz de quem viveu, sumir contigo pela morte natural, de mãos dadas nos instalar na memória dos filhos, a Casa virá e com ela o Reino, o pouso está próximo, por enquanto ainda o campo de batalha $[. . .]^{50}$

A cidade do Rio de Janeiro da obra conserva as características da cidade do mundo real e é apresentada pelo narrador como um cenário apocalíptico pontilhado pelo crime, violência e prostituição, marcas negativas que macula m o cotidiano do mundo citadino e que, na nossa leitura, são as marcas que pontilham o ritmo vertiginoso e à deriva da elaboração da linguagem literária. As ruas e os bairros, assim como o ritmo e a violência da capital fluminense, ao serem transportados para a obra, ganham uma nova dimensão, a dimensão da composição literária, do desenvolver da linguagem. A cidade ficcional da obra de Noll não intenta refletir a realidade do mundo dos homens, mas traz ainda, na errância dos dois personagens, a dura realidade da vida no mundo citadino, um espaço marcado pela frieza das relações interpessoais e da impossibilidade de uma estabilidade cotidia na. Um espaço que abriga duas dimensões, que Gilles Deleuze e Félix Guattari apresentam em "O liso e o estriado", do livro Mil platôs: capitalismo e 
51. DELEUZE E GUATTARI. Mil platôs: capitalismo e esquizofrenia, p. 180

52. DELEUZE E GUATTARI. Mil platôs: capitalismo e esquizofrenia, $\mathrm{p}$

$188-9$

53. DELEUZE E GUATTARI. Mil platôs: capitalismo e esquizofrenia, p. 214 esquizofrenia, como de naturezas contrárias, definidas por a mbos como espaço liso e espaço estriado.

O primeiro seria o espaço do movimento, do nomadismo o segundo, o da fixidez, do sedentarismo. O espaço urbano, a cidade, é definido pelos teóricos como um espaço estriado por excelência, mas que, no entanto, só existe comportando o espaço contrário: "Outras vezes ainda devemos lembrar que os dois espaços só existem de fato graças às misturas entre si: o espaço liso não pára de ser traduzido, transvertido num espaço estriado; o espaço estriado é constantemente revertido, devolvido a um espaço liso." ${ }^{51}$ A cidade se converteria no espaço contrário, o liso, no seu desenvolvimento espacial acelerado que desemboca em "imensas favelas móveis, temporárias, de nômades e trogloditas, restos de metal e de tecido, patchwork, que já nem sequer são afetado pelas estriagens do dinheiro, do trabalho ou da habitação." ${ }^{2}$ Assim, a cidade que comporta o cotidia no da organicidade, do trabalho, da estabilidade, ta mbém traz em si o espaço do movimento, da mobilidade, quando aquele que nela habita o faz à margem do seu estado organizacional: "Mesmo a cidade mais estriada secreta espaços lisos: habitar a cidade como nômade ou troglodita. Às vezes basta m movimentos, de velocidade ou de lentidão, para recriar um espaço liso." ${ }^{3}$
A errância do narrador de Noll e de sua Afrodite pelas ruas da Cidade, à margem de uma estabilidade social, é a transição de um espaço destinado à fixidez para o do movimento, do estriado ao liso, através da continuidade necessária para o desenvolvimento da linguagem. Ao estipular a não-nomeação para si e sua companheira e rejeitar a condição de cidadão inserido no mundo da ordem, do trabalho e da fixidez, relegando ao esquecimento qualquer indício de uma origem ou ancestralidade, o narrador propicia o movimento incessante em um espaço destinado à fixação. A cidade passa a ser a Cidade e o narrador, destinado ao profeta evangelista, e Afrodite, a anunciação de sua profecia, são tragados por essa Babilônia que se reflete na Copacabana de Noll, na qual a profecia do verbo divino se mistura com a embriaguez das mesas de bares e a sordidez da depravação sexual de seus habitantes:

[...] Afrodite bêbada desancou ordenando que eles nos olhassem e nos ouvissem porque tínhamos uma mensagem do verbo divino pra revelar, Afrodite berrava com a voz transtornada, que nos olhassem e ouvissem se quisessem a salvação porque naquela mesa ali bebendo chope feito porcos não conseguiriam a salvação [...] Afrodite continuou atacada, berrando que agora alardearia o verbo divino pelos quatros cantos do xadrez porque a redenção não tardaria e já se ouviam as trombetas dos anjos anunciarem mas ai de quem fica se 
empanturrando de chope pela Atlântica que nem porco, verá isso sim o sinal negro se rasgando no céu e a foice da morte eterna ceifar sua cabeça, a porta do camburão se abre, estamos diante de uma delegacia [...] todos entram em festa com a minha chegada, o carcereiro ri pra dentro da cela, ouço os berros apocalípticos de Afrodite, rasgam minha calça, a bicha começa a chupar meu pau, o mulato gordo enfia o dedo no meu cu, tira o pau pra fora e vai tentando com alguma coisa lambuzada pelo meu cu adentro, não sinto mais nada pra saber se entrou mesmo com que tamanho e dor, vagalhões oceânicos me atacam, afogado já não sinto nada [...]. ${ }^{54}$

A fala divina à qual o narrador de Noll se diz consagrado apresenta, assim, na sua enunciação literária, a inversão dos valores sagrados, permitindo elevar o sexo, usualmente concebido como profano, à condição de elemento sacro, elemento pelo qual o Apocalipse se fará a nunciar no espaço da Cidade, que não permite uma reversão do seu estado caótico para o estado da ordem. Ao ser transmutada na elaboração da escrita literária, a profecia do Apocalipse se revela como o elemento estruturador da narrativa de $A$ fúria do corpo, na qual o Reino que surge nas visões de João Evangelista é o corpo do sexo, que é o próprio corpo da escrita:

[...] me compadeço da Cidade hoje tão desfigurada como uma ocupação, peço silêncio e atenção à palavra de Afrodite, digo que ela foi enviada por Deus para matar a sede de vocês meus caros irmãos, notem sua voz iluminada, me pedem silêncio, apupos, que eu deixe a santa falar sozinha, ouço novamente as palavras de Afrodite, ela diz que os corpos ressurgirão da terra ao som da trombeta que nascerá de suas entranhas, que renascer sem corpo não adianta nada, é o corpo a casa do homem e os querubins invejam mortalmente esse corpo [...]. ${ }^{55}$

Desse modo, se locomovendo por uma forma de linguagem que se quer fazer distinguir da linguagem do mundo, a narrativa do narrador-apóstolo, e de sua a mante-profeta, se volta para as possibilidades do texto literário ao buscar a ambiguidade desde o seu primeiro momento na negativa de se autonomear, e se estendendo pela sua decisão imperiosa de deixar para trás qualquer ligação com o passado, demarcando o presente como ponto inicial da sua narração. A errância constante dos personagens pela Cidade e a impossibilidade de dela se evadir, pelas quais o desejo de repouso é inviável, levam à elaboração de uma escrita que se volta para a sua estruturação, percorrendo um caminho que não intenta estabelecer uma mensagem, não buscando assim o envio de um saber.

As muitas possibilidades de significação da narrativa de A fúria do corpo permitem a criação de novas leituras para simbologias já estratificadas, como as dos textos bíblicos 
aqui apresentadas, possibilitando assim uma reelaboração, uma reinvenção e uma reestruturação desses textos, antes consolidados a apenas um significado. Nessa nova leitura a escrita de João Gilberto Noll congrega esses elementos meta morfoseados, transmutando-os em elementos inerentes ao seu discurso, fazendo-os participar de sua narrativa em uma espécie de constituição própria, impossibilitando relações precárias entre esta escrita e suas novas leituras, através do movimento errante que se faz possível pela liberdade de significação do texto literário.

\section{REFERÊNCIAS}

BÍBLIA DE ESTUDO NVI/ organizador geral Kenneth Barker; coorganizadores Donald Burdick... [et al.]. — São Paulo: Editora Vida, 2003.

BLANCHOT, Maurice. A parte do fogo. Tradução de Ana Maria Scherer. Rio de Janeiro: Rocco, 1997.

BLANCHOT, Maurice. O livro por vir. Tradução de Leyla PerroneMoisés. São Paulo: Martins Fontes, 2005.

CAMPOS, Haroldo de. Éden. São Paulo: Perspectiva, 2004

DELEUZE, Gilles et GUATTARI, Félix. Mil platôs: capitalismo e esquizofrenia, vol. 5. Tradução de Peter Pál Pelbart e Janice Caiafa. São Paulo: Editora 34, 1997.
GRIMAL, Pierre. Dicionário da mitologia grega e romana. 4. Ed. Rio de Janeiro: Bertrand Brasil, 2000.

HEIDEGGER, Martin. A caminho da linguagem. Tradução de Marcia Sá Cavalcante Schuback. 4. Ed. Rio de Janeiro: Vozes, 2008

HESÍODO. Teogonia, a origem dos deuses. Tradução de Jaa Torrano. São Paulo: lluminuras, 2003

LELOUP, Jean-Yves. Apocalipse: clamores da revelação.

Tradução de Martha Gouveia da Cruz. 2. Ed. Rio de Janeiro: Vozes, 2009.

LELOUP, Jean-Yves. $\mathbf{O}$ evangelho de João. Tradução Guilherme João de Freitas Teixeira. Petrópolis, Rio de Janeiro: Vozes, 2000.

NOLL, João Gilberto. A fúria do corpo. Rio de Janeiro: Record 2008

PAZ, Octavio. A chama dupla: Amor e erotismo. Tradução de José Bento. Lisboa: Assírio \& Alvim, 1995.

REEBER, Michel. Religião: termos, conceitos e idéias. Rio de Janeiro: Ediouro, 2002.

SISSA, Giulia et DETIENNE, Marcel. Os deuses gregos. São Paulo: Companhia das Letras, 1990.

Recebido em: 03-11-2018 Aceito em: 29-11-2018. 